\title{
Pronominal right-dislocation in Norwegian
}

\section{Glossa}

a journal of general linguistics

\author{
RESEARCH
}

\section{KAJA BORTHEN [1] \\ ELENA KARAGJOSOVA (D)}

*Author affiliations can be found in the back matter of this article

\begin{abstract}
The goal of the paper is to propose a holistic analysis of the discourse properties and the interpretational effects of pronominal right-dislocation in Norwegian. Previous research has suggested that this is a topic construction, and it has been shown that the right-dislocated pronoun may affect reference assignment, is sometimes used in cases of discourse breaks, is associated with contrastiveness, and may lead to interpretational effects such as "emphasis" and "mitigation". Based on Norwegian authentic corpus material, Givón's (1983a) notion of marked constructions, and Sperber and Wilson's $(1986 / 1995)$ relevance theory, we present a novel analysis that connects the various properties of the construction together. A central aspect of our analysis is the assumption that marked constructions increase the accessibility of contrastive interpretations, which in turn may trigger the derivation of certain types of implicatures. Since the analysis is mainly based on assumptions about human cognition, the study makes cross-linguistic predictions despite its focus on one language.
\end{abstract}

CORRESPONDING AUTHOR:

\section{Kaja Borthen}

NTNU Trondheim, NO

kaja.borthen@ntnu.no

\section{KEYWORDS:}

contrast; marked construction; relevance; right-dislocation; topicality

TO CITE THIS ARTICLE: Borthen, Kaja and Elena Karagjosova. 2021. Pronominal right-dislocation in Norwegian. Glossa: a journal of general linguistics 6(1): 85. 1-25. DOI: https://doi.org/10.5334/ gjgl.1025 


\section{Introduction}

Right-dislocation is the phenomenon in which a sentence-internal nominal phrase co-occurs with a coreferential phrase to the right of the sentence, and the two expressions share argument role. The phenomenon is illustrated by the italicized sentence in (1) (Ward \& Birner 2004: 168).

(1) Below the waterfall (and this was the most astonishing sight of all), a whole mass of enormous glass pipes were dangling down into the river from somewhere high up in the ceiling! They really were ENORMOUs, those pipes. There must have been a dozen of them at least, and they were sucking up the brownish muddy water from the river and carrying it away to goodness knows where. (R. Dahl, Charlie and the Chocolate Factory, 1964: 74-75)

According to Ziv (1994: 641), the function of right-dislocation in English is to introduce or re-introduce an evoked discourse entity for future reference as a potential topic. The prototypical referent of a right-dislocated phrase is an entity that is accessible in the discourse, but not maximally accessible, according to Ziv, and she argues that this is the reason why right-dislocation in English is acceptable only when the right-dislocated phrase has a richer descriptive content than the sentence-internal correlate. (2), for instance, is ungrammatical in English.

(Ziv 1994: 643)

*The picture is beautiful, it.

Ziv explains the illformedness of (2) by claiming that the pronominal form and the rightdislocation construction contribute conflicting information: Whereas the unaccented personal pronoun signals that the referent is maximally accessible, the right-dislocation construction signals that the referent is not maximally accessible.

Although seemingly plausible for standard English, Ziv's explanation for the illformedness of (2) is not in accordance with the fact that pronominal right-dislocation is fully acceptable in some languages, e.g. Norwegian (Askedal 1987; Fretheim 1995; 2000; Faarlund et al. 1997; Vangsnes 2008; Eiesland \& Vindenes 2017; Borthen 2018), Swedish (Teleman \& Wieselgren 1970; Jörgensen 1976; Nyholm 1986), and French (Ashby 1988). Pronominal right-dislocation is also attested in some varieties of vernacular oral English (Wright 1905; Carter \& McCarthy 1995: 150; Shorrocks 1999; Biber et al. 1999: 958; Snell 2018; Mycock 2019).

The authentic example in (3), from Borthen (2018: 434), illustrates the phenomenon for Norwegian. The subject han 'he' is the correlate for the right-dislocated pronoun han 'he'.

(3) (The speaker is talking about her son, who has a handicap)

Ja, det hender nok jeg kan være sårbar på Torkilds annerledeshet. Men kanskje sårer det meg mer at folk som kommer til oss hilser på både Ingrid Elise og meg, men i sin ubetenksomhet «glemmer» Torkild. Han er liksom ikke medregnet, han.

'Yes, I guess it does happen that I am being vulnerable because of Torkild being different. But what hurts me the most, I think, is that people who visit us say hello to Ingrid Elise and me, but thoughtlessly «forget» Torkild. He sort of doesn't count, HE. ${ }^{1}$

The grammaticality of examples such as (3) means that the illformedness of (2) cannot be due to inherent and general properties of pronouns and the right-dislocation construction per se. Rather, there must be differences among languages and language varieties with respect to what types of right-dislocated constituents are syntactically licensed. Why Norwegian allows for this syntactic constellation whereas other languages do not, is not the focus of this paper. Rather, our focus is on the construction's discourse properties and interpretational effects.

As the literature review in section 2 will show, a variety of linguistic parameters have been proposed as being relevant to pronominal right-dislocation in Norwegian. These include

\footnotetext{
1 We do not gloss Norwegian text excerpts unless there are specific reasons to. The effects of the right-dislocated pronouns cannot always be captured in a short paraphrase, as they may for instance affect coherence or lead to several weak implicatures. Therefore, the English translations contain a right-dislocated pronoun formatted in small caps in the position of the Norwegian right-dislocated pronoun.
}

Borthen and Karagjosova Glossa: a journal of general linguistics DOI: $10.5334 /$ gjgl.1025 
discourse-related properties such as topicality, reference maintenance, reference assignment, discourse (dis)continuity, and contrast. In addition, it has been observed that the construction often has specific interpretational effects, sometimes described as "emphasis" and "mitigation" (Eiesland \& Vindenes 2017). To illustrate, the right-dislocated pronoun in (3) intuitively improves the text's discourse coherence, it highlights a contrast between the fact that Torkild does not count whereas other people count, and it has an "emphasis" effect in that the speaker appears as more emotionally hurt than she would have without the right-dislocated pronoun. Other effects may arise in other examples.

That right-dislocation in general can have affective, attitudinal or interpersonal effects has been observed for other languages as well (see e.g. Ashby 1988; Aijmer 1989; Carter \& McCarthy 1995: 151; 1997; Carter et al. 2000; Timmis 2010: 11; Snell 2018; Mycock 2019). What has been missing in the literature, is a discussion of whether there is a connection between the discourse-related properties of right-dislocation, such as the construction's assumed status as a topic construction and its effect on discourse coherence, and interpretational effects such as "emphasis" and "mitigation". Our main goal in this paper is to explicate the connection between these two linguistic aspects of the construction.

We argue with Givón (1983a) that linguistic structures can be ranged with respect to their degree of markedness (i.e. phonological, semantic and mophosyntactic complexity), and we argue that pronominal right-dislocation is a marked construction in this sense. More precisely, we claim that pronominal right-dislocation in Norwegian is a marked topic construction whose function is to indicate a lower degree of predictability of the sentence's topic or topic-comment structure than what would have been expected for the minimally distinct structure without pronominal right-dislocation. In effect, the construction is used to indicate a shift of sentence topic from the previous utterance to the current one, and/or that what is stated about the topic referent contrasts with what is expected or given. This explains why the construction can affect discourse coherence and reference assignment, why it is often used in cases of eventive breaks, and why it affects pragmatic interpretations more generally. Our analysis builds on Reinhart's (1981) classical "aboutness" definition of sentence topics and the relevance-theoretic view on pragmatic inferencing (Sperber \& Wilson 1986/1995). Relevance theory plays a particularly central role by providing the explanatory link between the contrastive aspect of the construction and its pragmatic effects, as well as explaining how one construction can have two diametrically opposite effects ("emphasis" or "mitigation"), depending on utterance content and context.

The analysis is based mainly on authentic corpus material. We have performed a reanalysis of 289 examples of pronominal right-dislocation in Norwegian, first presented and analyzed in Borthen (2018). The data are from The Oslo Corpus of witten texts (the 'bokmål' part), which is a collection of novels, magazine/newspaper texts, and legal texts. ${ }^{2}$

In the next section, we present a literature review on Norwegian pronominal right-dislocation, structured according to the most central themes in the literature. We elaborate on several problems and puzzles that have remained partly unresolved until now, and the section gives an overview of insights and remaining questions. In section 3, we present our analysis, with a focus on the connection between the construction's discourse properties and its interpretational effects. Section 4 concludes the paper and points to some topics for further research.

\section{Previous research on pronominal right-dislocation in Norwegian}

\subsection{Topicality}

There is consensus in the literature that pronominal right-dislocation in Norwegian is connected to topicality (see Askedal 1987; Fretheim 1995; 2000; Faarlund et al. 1997; Vangsnes 2008; Borthen 2018). More precisely, unaccented, right-dislocated pronouns are assumed to encode the sentence topic.

2 Pronominal right-dislocation occurs mainly in oral speech. Consequently, the data that are presented in this paper are either from quotations in newspapers or magazines (i.e. from interviews), or from dialogues in novels. The Oslo Corpus was chosen as the empirical source for the investigation of pronominal right-dislocation due to its rich annotation and advanced search system, which makes it possible to delimit searches to the target phenomenon. 
A sentence topic can be described informally as "what the sentence is about", as opposed to "what is predicated about the topic" (cf. Dik 1978; Reinhart 1981; Lambrecht 1994; Gundel \& Fretheim 2004). As for what sentence topics are on a deeper level, and how to define the category more strictly, there are different classifications and definitions around. For the analysis of pronominal right-dislocation, the classical view on sentence topics proposed by Reinhart (1981) is both descriptively and intuitively appropriate, and will be adopted here. According to this account, sentence topics are entries under which the sentence's proposition is stored in memory, if accepted to be true (Reinhart 1981: 80). The remaining non-topical part of the sentence is labelled comment.

Reinhart points out that a sentence topic is typically but not necessarily realized as the subject of the clause and as definite or pronominal, and it is typically but not necessarily already given in the discourse. The tendency for topics to represent given information (with potential effects on syntactic function and nominal form) can be seen as a secondary effect of its cognitive function as a "memory tag": It is more efficient to successively store information under one memory tag which is repeated in subsequent sentences, than to constantly change the locus for the representation of the new information.

Reinhart (1981) acknowledges that some sentence structures may encode a specific topiccomment structure. Left-dislocation is one such construction. In the sentence (As for) Peter, he never arrived, Peter is necessarily the sentence topic. However, according to Reinhart (ibid.), most sentence structures may realize different topic-comment structures in different contexts. The sentence Max saw Rosa, for instance, has Max as the sentence topic when answering the question Who did Max see? whereas it has Rosa as the sentence topic when answering the question Has anybody seen Rosa yesterday?. Thus, information structure is a fundamentally pragmatic notion in Reinhart's sense, and one way of testing whether a linguistic form marks the sentence topic, is to test what questions it answers in a natural way.

As described in Borthen (2018), judgments of such question-answer pairs suggest that pronominal right-dislocation in Norwegian is a topic construction in Reinhart's (1981) sense. Consider the two alternative answers to A's question in (4) and compare them to the parallel data in (5) (from Borthen 2018: 408). (4B2) is pragmatically unacceptable.
A: Nevn en lingvist.
'Mention a linguist.'
B1: Chomsky er lingvist.
Chomsky is linguist
'Chomsky is a linguist.'
B2: \#Chomsky ${ }_{\mathrm{i}}$ er lingvist, han $_{\mathrm{i}^{*}}$
Chomsky is linguist he
'Chomsky is a linguist.'
A: Hvilket yrke har Noam Chomsky? Er ikke han politiker?
'What occupation does Noam Chomsky have? Isn't he a politician?'
B: Nei. Chomsky ${ }_{i}$ er lingvist, han ${ }_{i}$ no Chomsky is linguist he 'No. Chomsky is a linguist.'

As Borthen points out, a crucial difference between the unacceptable answer (4B2) and B's answer in (5), has to do with information structure. In (5), the referent of the right-dislocated pronoun and its correlate is part of the topic settled by A's question, and pronominal rightdislocation is natural. In (4), the referent of the right-dislocated pronoun and its correlate is part of the utterance's comment, and pronominal right-dislocation is not natural.

There are also syntactic pieces of evidence that suggest that pronominal right-dislocation in Norwegian is a topic construction. As first observed by Askedal (1987), the sentence-internal correlate must be either a main clause subject or a main clause fronted object. In contrast, a direct object in the canonical object position cannot function as the correlate of a rightdislocated pronoun. This is shown in (6) and (7) (from Borthen 2018: 408). 
a. (Sentence-initial subject correlate)

$\mathrm{Vi}_{\mathrm{i}}$ skal ha pizza til middag, $\mathbf{v i}_{\mathrm{i}}$. we will have pizza for dinner we

'We are going to have pizza for dinner.'

b. (Non-initial subject correlate)

Pizzaen skal $v i_{i}$ ha til middag, $\mathbf{v i}_{i}$. pizza.DEF will we have for dinner we 'The pizza we will have for dinner.'

a. (Fronted object correlate)

Pizzaen $_{\mathrm{i}}$ skal vi ha til middag, den ${ }$. pizza.DEF will we have for dinner it.M 'The pizza we will have for dinner.'

b. (Non-fronted object correlate)

*Vi skal ha pizzaen $_{\mathrm{i}}$ til middag, den ${ }_{\mathrm{i}}$ we will have pizza.DEF for dinner it.M 'The pizza we will have for dinner.'

Since subjects and fronted objects are more typical topic expressions than are canonical objects (see e.g. Lambrecht 1994: 132; Ward \& Birner 2004: 158-163), the data in (6) are in line with the hypothesis that pronominal right-dislocation is connected to topicality.

Other syntactic patterns point in the same direction. For instance, it is not possible to rightdislocate a Norwegian expletive pronoun (cf. Søfteland 2014: 34ff). As argued in Borthen (2018), this is compatible with the topicality hypothesis since an expletive is semantically empty and thus cannot represent "what the sentence is about".

A construction that is compatible with pronominal right-dislocation is left-dislocation. As illustrated by the authentic example in (8) (Borthen 2018: 410), a right-dislocated pronoun and its correlate may be coreferential with a left-dislocated constituent.

Men [Vibeke og han], de , $_{i}$ var ikke slik, de ${ }_{i}$. but Vibeke and he they were not such they 'But he and Vibeke, they were not like that.'

Left-dislocation is assumed to encode the sentence topic in Norwegian (Faarlund et al. 1997: 907). Thus, Borthen (2018) argues that it is as expected that a right-dislocated pronoun and its corelate may be coreferential with a left-dislocated constituent, given that pronominal rightdislocation is a topic construction. One question that remains to be answered, is why a speaker would want to mark the topic twice. This question will be brought up in section 3.5.

The data in (4)-(8) above are as expected, given the hypothesis that a right-dislocated pronoun encodes the sentence topic. However, some authors claim that there is also some counter evidence. Askedal (1987) points out that a right-dislocated pronoun can be modified by a focus adverb such as også 'also'. One example is (9) (cf. Borthen 2018: 410).

$$
\begin{aligned}
& \text { Per }_{i} \text { trenger omsorg han }{ }_{\mathrm{i}} \text { også. }^{3} \\
& \text { Per needs care he too }
\end{aligned}
$$

'Also Per needs care.'

According to Borthen (2018), examples like this challenge the assumption that pronominal right-dislocation is a topic construction, since focus adverbs such as også 'also' are assumed to mark rhematic (and thus non-topical) information (cf. König 1991; Fretheim 1999; Faarlund et al. 1997: 915-920). ${ }^{4}$ Based on data such as these, it seems necessary to distinguish between unaccented, non-modified right-dislocated pronouns (that always represent sentence topics), and accented and possibly modified pronouns (that may represent non-topical information). Along these lines, both Askedal (1987) and Fretheim (2000) conclude that there are two kinds

The pronoun in (9) necessarily achieves word accent.

Karagjosova (2012) has shown that focus adverbs may in some cases modify topical information, but han også 'he too' in (9) can clearly designate rhematic information, for instance in a discussion about who needs care. 
of pronominal right-dislocation in Norwegian. Such disjunctive analyses are not empirically wrong, but they are stipulative. In section 3, we will use Givón's (1983a) notion of markedness to provide a rationale for why the information status of various types of right-dislocated constituents may vary.

Another unresolved question that the previous accounts do not solve, is the following: Since the correlate of the right-dislocated pronoun is necessarily a subject or a fronted object - which are prototypical topic expressions (see e.g. Lambrecht 1994) - why add the right-dislocated pronoun in addition? Why mark a default topic as the topic? As will be made clear in section 3 , we believe the answer to this question points to the very essence of the construction, which is, in our view, not merely to encode the sentence topic, but to present it as marked.

\subsection{Reference-related properties}

\subsubsection{The nominal forms}

Borthen (2018) investigated the distribution of forms among 289 authentic examples of rightdislocated pronouns in a corpus consisting of newspaper and magazine texts, novels and legal documents in Norwegian. The distribution of forms among these correlates and right-dislocated (RD) pronouns is presented in Table 1. The percentages in the right-hand column are added by us.

\begin{tabular}{lllllllllll}
\hline RD pron. & $\begin{array}{l}\text { jeg } \\
\text { I }\end{array}$ & $\begin{array}{l}\text { du/De } \\
\text { you. SG }\end{array}$ & $\begin{array}{l}\text { he } \\
\text { he }\end{array}$ & $\begin{array}{l}\text { hun } \\
\text { she }\end{array}$ & $\begin{array}{l}\text { den } \\
\text { it.M }\end{array}$ & $\begin{array}{l}\text { det } \\
\text { it.N }\end{array}$ & $\begin{array}{l}\text { vi } \\
\text { we }\end{array}$ & $\begin{array}{l}\text { dere } \\
\text { you.PL }\end{array}$ & $\begin{array}{l}\text { de } \\
\text { they }\end{array}$ \\
\hline Correlate & & & & & & & & & & \\
\hline Pronoun & 79 & 40 & 10 & 3 & 1 & 61 & 9 & 0 & 4 & $207(72 \%)$ \\
\hline$\varnothing$ (zero) & 7 & 20 & 0 & 0 & 0 & 13 & 0 & 1 & 0 & $41(14 \%)$ \\
\hline Proper name & - & - & 13 & 2 & 2 & 1 & - & - & 4 & $22(8 \%)$ \\
\hline Definite NP & - & - & 1 & 1 & 8 & 2 & - & - & 3 & $15(5 \%)$ \\
\hline Indefinite NP & - & - & 0 & 0 & 0 & 0 & - & - & 3 & $3(1 \%)$ \\
\hline Sentence & - & - & - & - & - & 1 & - & - & - & 1 \\
\hline Sum & 86 & 60 & 24 & 6 & 11 & 78 & 9 & 1 & 14 & $289(100 \%)$ \\
\hline
\end{tabular}

According to Table 1, the correlate of a Norwegian right-dislocated pronoun is usually an identical pronoun $(72 \%)$ or a zero subject $(14 \%)$. Proper names $(8 \%)$, definite noun phrases (5\%) and indefinite noun phrases (1\%) are less common correlate forms. These results are almost identical to the findings of Askedal (1987), who looked at right-dislocation in children's novels. The distribution of forms in Table 1 is parallel to the distribution of forms for Norwegian subjects in spontaneous oral speech (see Søfteland 2014) and for sentence topics cross-linguistically (see e.g. Lambrecht 1994: 165-176). Only 3 of the correlates in Table 1 are fronted objects. ${ }^{5}$

One example from the data in Table 1 with a non-pronominal correlate is presented in (10).

$$
\begin{aligned}
& \text { Du, mennesker gir seg ikke tid til å være inaktive. Det er synd. For det skjer så } \\
& \text { utrolig mye positivt når man tillater seg ro. Alle blomster må jo hvile før de kan } \\
& \text { blomstre. Potteplanter kan tillate seg å være visne og henge med hodet hele } \\
& \text { vinteren, de. Så blomstrer de! } \\
& \text { 'You see, people do not allow themselves to be inactive. That is a pity. Because so } \\
& \text { many positive things happen when you allow yourself peace. After all, all flowers } \\
& \text { must rest before they can bloom. Houseplants can allow themselves to wither and } \\
& \text { hang their heads down all winter, THEY. Then they bloom!' }
\end{aligned}
$$

The referent of the right-dislocated pronoun in (10) is new to the discourse. This example and the numbers in Table 1 illustrate a point made in section 2, namely that although topics tend to be already given in the discourse, they may also correspond to brand new discourse entities.
Table 1 The form of rightdislocated pronouns and their correlates. 
According to Lambrecht (1994: 165), this is especially likely when the discourse referent is indirectly linked to the previous discourse, which is the case in (10).

As for the specific type of right-dislocated pronouns, Table 1 shows that only nominative case is permitted, and the pronoun is most often the first-person singular pronoun jeg ' $\mathrm{I}$ ', followed by the neuter singular pronoun det 'it', and the second-person singular pronoun $d u$ 'you'. This pattern, too, is similar to that of subject pronouns in Norwegian informal speech (see Søfteland 2014).

To sum up, the correlate of a Norwegian right-dislocated pronoun tends to be pronominal or zero but it may have other forms. Overall, there does not seem to be anything special about the correlate's form in sentences with pronominal right-dislocation compared to that which is expected for canonical subjects (and fronted objects) in oral speech in Norwegian.

\subsubsection{Effects on reference assignment}

Even though there is nothing special about the nominal forms involved in pronominal rightdislocation, the construction may still be systematically linked to referent accessibility, thereby influencing reference assignment. Fretheim (1995) uses constructed examples similar to (11) and (12) to illustrate that the addition of a right-dislocated pronoun may affect the interpretation of the correlate.

$($ den $=$ 'that snake over there')

A: Det der er en hoggorm.

'That's a viper'

B: Nei. Den har et siksakband over ryggen.

no it.M has a zigzag.band down back.DEF

'No. It has a zigzag band down its back.'

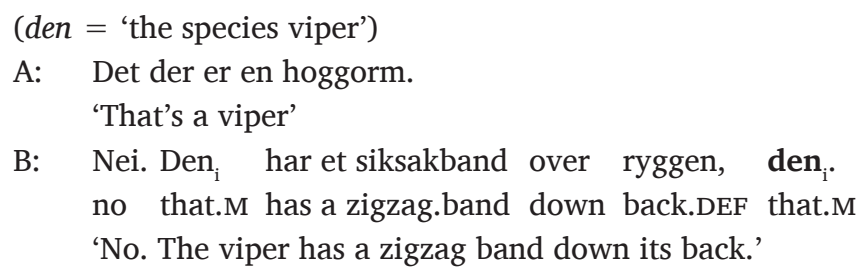

Whereas the subject den 'it.M' in (11) is interpreted as referring to the snake that person A was talking about, the pronoun den 'it.M' in (12), ${ }^{6}$ with an accompanying right-dislocated pronoun, is more naturally interpreted as referring to the species viper.

As Fretheim (1995) points out, the individual snake in the physical surroundings in (11) is in the addressee's current centre of attention after A's utterance. That is, it is "in focus" in the sense of Gundel et al. (1993), whereas the species viper is only (indirectly) activated. Gundel et al.'s model is represented below with associated English forms:

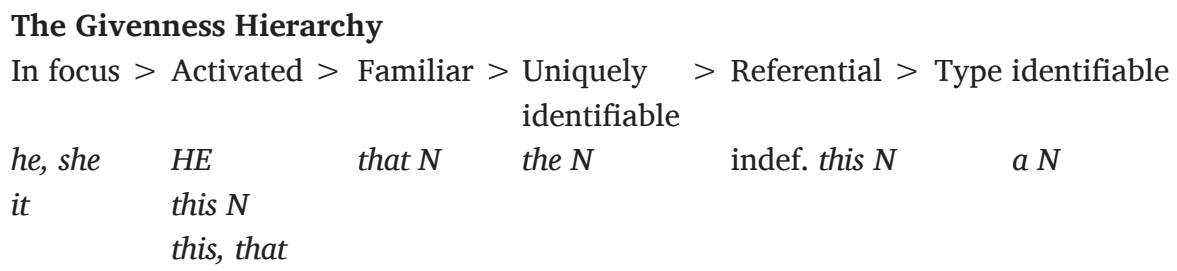

According to this model, various determiners and pronominal forms conventionally signal one of the six cognitive statuses on the Givenness Hierarchy as part of their semantics. Since the higher statuses entail the lower ones, the prediction is that a nominal form is appropriate when the referent has the cognitive status that the nominal form encodes (and is placed under in the model), or any higher cognitive status. Based on data such as (11) and (12), Fretheim (1995: 33-34) concludes that the discontinuous pronominal expression $\operatorname{den}_{i} \ldots$, den $_{i}\left({ }^{\prime} i_{i} \ldots\right.$ it $_{i}$ ') does not

\footnotetext{
6 The pronominal subject in (12) is most naturally accented whereas the pronoun in (11) is most naturally unaccented.

$7 \quad$ Gundel et al.'s (1993) term 'in focus' means 'represented in short-term memory and moreover in current
} center of attention' and should not be confused with the information structure category 'focus'. 
encode the highest cognitive status, as does the single pronoun den 'it', but only the next-tohighest status activated. This, he argues, explains why the subjects in (11B) and (12B) achieve different interpretations.

Although we agree in Fretheim's intuitions concerning the interpretations of (11) and (12), we find his explanation questionable. If his analysis were correct, there should be a systematic difference with respect to the cognitive status of pronominal subjects and fronted objects that occur alone and those that occur with an accompanying right-dislocated pronoun, but Fretheim presents no corpus study or any authentic examples to back up his analysis. On the contrary, his analysis is based on one single constructed example. There is also a more fundamental problem with Fretheim's approach. In the Givenness Hierarchy framework, each nominal form is stipulated to encode a cognitive status as part of the determiner's or pronoun's semantics. This means that the correlation between a form and a cognitive status is specified in the mental lexicon. According to Fretheim's approach, all pronouns would have to be listed at least twice in the lexicon; once with the cognitive status they encode alone and a second time with the cognitive status they encode as the correlate of a right-dislocated pronoun. If the same approach is assumed for each type of correlate (indefinite, definite, demonstrative etc.), this will result in a very high number of discontinuous nominal forms in the lexicon, and the number would be even further multiplied with different types of right-dislocated constituents. We take this approach to be cognitively implausible, both because it seems unnecessarily stipulative and because it is not clear that it would even be possible to state a different semantics for each type of combination of correlate and right-dislocated constituent.

The conclusion of this section is that a right-dislocated pronoun may in some exceptional cases affect reference assignment, but the function of pronominal right-dislocation must be something else than encoding cognitive status in Gundel et al.'s (1993) sense. In section 3.6, we will present our alternative explanation for the data in (11) and (12), which does not rest on encoded semantics.

\subsubsection{Reference maintenance}

Another approach to pronominal right-dislocation is put forth by Averintseva-Klisch (2006; 2008a; b; c). According to this approach, right-dislocated phrases mark the present and upcoming discourse topic, where discourse topic is defined as "the discourse referent that is stably activated in the discourse representation during the reception of a particular discourse segment, or, in other words, the referent about which the current discourse segment is" (Averintseva-Klisch 2008c: 225). An illustrating example from German, is (13), where Madame Dutitre is presented as the discourse topic, according to Averintseva-Klisch.

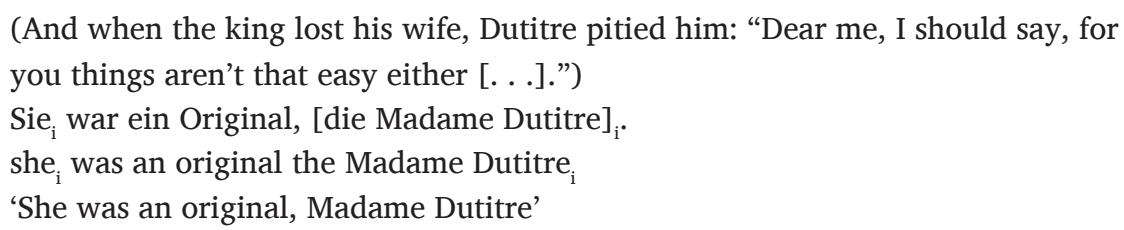

As for pronominal right-dislocation in languages such as Norwegian, Averintseva-Klisch (2008a: 234) says that this seems to her to be the clearest case of a discourse topic marking function of right-dislocation. Firstly, because adding a pronoun cannot serve the function of reference clarification (as may descriptively rich phrases), and secondly because personal pronouns are traditionally assumed to be the preferred means for referring to discourse topics. Moreover, Averintseva-Klisch (2008c: 226) argues that being situated at the right periphery of the sentence, a topic which is marked through right-dislocation is predestined to influence the subsequent discourse, which means that in the default case, it will be the topic not only for the present segment but also for the following one. If this generalization holds, the expectation is that a discourse entity referred to by a right-dislocated pronoun will be particularly likely to be referred to subsequently.

We see no theoretical obstacle to Averintseva-Klisch's analysis, but it needs empirical support. To test its validity, we performed a quantitative corpus study. We selected the 207 text excerpts with pronominal correlates in Table 1 (from The Oslo Corpus), and then collected a parallel data set in the same corpus without pronominal right-dislocation. That is, for each example with 
a right-dislocated pronoun, we searched for a sentence with an identical subject (or fronted object) and identical sentence predicate, and among the list of hits, we picked the first one with a similar interpretation as the original sentence with pronominal right-dislocation. The resulting data set consists of 207 "minimal pairs" of text excerpts with and without pronominal right-dislocation. One such pair is presented in (14).

a. (Corpus data with pronominal right-dislocation)

En gang i tiden var tekstil og konfeksjon Norges største landbaserte industri. Der Bergens-regionen var et dynamisk tyngdepunkt. Det er lenge siden, det! Men NOE finnes igjen. [...]

'Previously, textile and clothing were Norway's largest land-based industry. With the Bergen region as a dynamic centre. That's a long time ago, THAT! But SOMETHING is left.' [...]

b. (Corpus data without pronominal right-dislocation) Gustav mente at for ti år siden hadde de nok syntes det var morsomt å base i snøen på haugen også, og la seg rulle nedover skråningen til de kunne skremme folk på gaten som levende snømenn, men det var lenge siden. Det som deprimerte Gustav Valberg aller mest var [...]

'Gustav was of the opinion that ten years ago, they would have found it amusing to play in the snow on the heap, too, and roll down the hill and scare people in the streets as living snowmen, but that was a long time ago. What made Gustav Valberg most depressed, was [...]

Reference maintenance was measured by counting the number of sentences in which the target referent was mentioned subsequently, within a limit of five sentences. In (14a) and (14b), none of the referents of the target pronouns (det 'that') are mentioned subsequently, so the value for reference maintenance is 0 in both cases.

We did not find any significant difference between the two categories with respect to subsequent mention. For both categories the average number for subsequent reference within the 5 next sentences is close to 1 , i.e. 0,99 for examples with pronominal right-dislocation and 1,09 for canonical pronouns. Thus, according to our investigation, pronominal right-dislocation does not increase the likelihood of subsequent mention of the referent, which is contrary to what one might expect from Averintseva-Klisch' (2008c) claim that pronominal right-dislocation marks the present and upcoming discourse topic.

There are also some differences between (14a) and (14b) that have no explanation on AverintsevaKlisch' account. (14a), with a right-dislocated pronoun, has an emphatic interpretation not found in (14b), and intuitively, there is a lower degree of discourse coherence between the target sentence and the previous discourse in (14a) than in (14b). These differences between (14a) and (14b) are not coincidental on our account.

\subsection{Eventive breaks}

Fretheim (1995: 34) points out that the use of a right-dislocated pronoun is sometimes related to breaks in the discourse. He uses the constructed examples in (15) to illustrate this. B1 and $\mathrm{B} 2$ are two competing follow-ups to A's utterance. B1, with pronominal right-dislocation, is the more natural response of the two.

A: I dag snakket jeg med en som kjente deg fra den tida da du bodde på Kirkenær Axel Aarvoll.

'Today I spoke with someone who knew you from the period when you were living in Kirkenær - Axel Aarvoll.'

B1: Han $_{\mathrm{i}}$ var gift med søskenbarnet mitt en gang i tida, han . he was married with cousin.DEF mine one time in time.DEF he 'He was once married to my first cousin, HE.'

B2: \#Han var gift med søskenbarnet mitt en gang i tida. he was married with cousin.DEF mine one time in time.DEF 'He was once married to my first cousin.' 
If person A had continued to talk about what happened when A met Axel Aarvoll, using an unaccented pronoun in subject position without a right-dislocated pronoun would have been the natural choice. But as Fretheim points out, when person B interrupts A's story by mentioning that Axel has been married to his second cousin, using a right-dislocated pronoun is more coherent than not. According to Fretheim, it is the new turn in the story that triggers and favors the use of the right-dislocated pronoun. Similar authentic data are presented in Borthen (2018).

Data such as those in (15) illustrate that pronominal right-dislocation is particularly natural in cases of minor breaks in the discourse, but so far, it has not been clear how to connect this fact to the other properties of the construction, such as its assumed status as a topic construction. In section 3, we will argue that pronominal right-dislocation is not only a topic construction, but a marked topic construction that is used in cases of a lower degree of predictability and continuity than normally expected for topics, e.g. in cases of topic shift. This explains why pronominal right-dislocation is particularly natural in (15), since person A's utterance is about what happened that day whereas B's response is about Axel Aarvoll.

\subsection{Contrast}

Borthen (2018) shows that pronominal right-dislocation is often used when a contrastive meaning aspect is available in the discourse, and in such cases, the construction is particularly natural. This is illustrated in (16)-(18), from Borthen (2018).

- Det er jævla å være separert? Det kom som et spørsmål. Jeg visste ikke hva jeg skulle svare. - Syns egentlig det er ok, jeg. Verre å være gift.

'- It's awful to be separated? It was formulated as a question. I didn't know what to answer. - In fact, (I) think it is ok, I. It's worse to be married.'

In (16), the speaker's view that it is ok to be separated opposes the addressee's implicated view that it must be awful to be separated, and this contrastive meaning aspect is highlighted by the right-dislocated pronoun. Another example discussed in Borthen (2018), is (17).

De kommer gjerne et par dager før de skal lese opp, for å nyte luksusen. Ja, Ingvar Ambjørnsen kommer tre-fire dager før, han.

'They [the authors] usually arrive a couple of days ahead of the performance, to enjoy the luxury. That is, Ingvar Ambjørnsen arrives three to four days ahead, HE.'

(17) describes two facts that can be perceived of as contrasting. Whereas most of the authors arrive two days ahead of the performance, Ingvar Ambjørnsen arrives 3-4 days in advance. The use of a right-dislocated pronoun is particularly natural in this context, and its presence emphasizes the contrast between the behavior of Ambjørnsen and the other authors.

(18) below illustrates that a sentence with a right-dislocated pronoun may achieve a contrastive interpretation even in cases where this contrast is not licensed by the preceding context.

$$
\begin{aligned}
& \text { Solen er varm - den kaster sine varme stråler på ham, men så må han ikke sitte her } \\
& \text { lenger. Han må videre. For han har likesom ikke lov til å sitte slik i solen, han. } \\
& \text { 'The sun is hot - it is throwing its warm rays onto him, but now he cannot sit here } \\
& \text { any longer. He must continue. Because he is sort of not allowed to sit like this in the } \\
& \text { sun, HE.' }
\end{aligned}
$$

As reported on in Borthen (2018), the prohibition against sitting in the sun is presented as something that holds for the male character, as opposed to others. Borthen argues that since there is no context-driven bias towards a contrastive interpretation in (18), it must be the right-dislocated pronoun that makes this contrastive interpretation particularly highly accessible.

There are many types of contrast. According to Borthen (2018), pronominal right-dislocation gives rise to the particular type of contrast defined in (19).

There is contrast between two propositions $p$ ([SUBJ PRED $\left._{1}\right]$ ) and $q$ ([ $\left.\left[\mathrm{SUBJ}_{2} \mathrm{PRED}_{2}\right]\right)$ if $p$ and $q$ have opposite polarity while $\operatorname{PRED}_{1}$ and $\mathrm{PRED}_{2}$ are identical.

(Borthen 2018: 425) 
The idea behind (19) is that a right-dislocated pronoun that is part of an utterance used to communicate a proposition $p$ of the format [SUBJ ${ }_{1}$ PRED $_{1}$ ], encourages the addressee to look for a contrasting proposition $q$ of the format $\left[\mathrm{SUBJ}_{2} \mathrm{PRED}_{2}\right]$, with the same sentence predicate as in $p$, but with opposite polarity. For instance, (19) is intended to cover the contrast between the propositions 'Peter is sleeping' and 'Mary is not sleeping'.

(19) underspecifies how accessible the contrasting proposition $q$ is when a right-dislocated pronoun is used. It may e.g. be an entailment of the previous utterance (as in (17)), an implicature communicated in the previous discourse (as in (16)), or a contextual assumption established as part of the interpretation process based on the content of the utterance (as in (18)).

Borthen's formulation of (19) is, however, not entirely accurate. Given that the sentence predicate is the locus for the negation, it is not correct to say that $p$ and $q$ have opposite polarity while $\mathrm{PRED}_{1}$ and $\mathrm{PRED}_{2}$ are identical. It is also not obvious from (19) whether it covers fronted objects as well as subjects. And finally, there is a more fundamental problem. Borthen claims that pronominal right-dislocation is a construction with an encoded procedural semantics in the sense of Blakemore (1987) and Wilson \& Sperber (1993), and the contrastive meaning aspect in (19) is seen as part of this semantics. The problem is that contrast does not seem to be involved in all cases with pronominal right-dislocation. For instance, there is intuitively no contrastive aspect of the kind presented in (19) involved in (15), where the right-dislocated pronoun merely has a discourse structuring effect. This suggests that contrastiveness is not semantically encoded by the construction, although the construction makes such contrastive interpretations more accessible.

In section 3, we propose a refined version of Borthen's (2018) definition of the contrast involved in pronominal right-dislocation, and we argue that marked constructions in general heighten the accessibility of contrastive interpretations. This means that the contrastive meaning aspect of pronominal right-dislocation will often, but not necessarily, play a role in the interpretation process.

\subsection{Interpretational effects}

The interpretational effects of pronominal right-dislocation have been described in various ways in the Norwegian literature. Askedal (1987) calls pronominal right-dislocation "a grammaticalized means for creating an atmosphere of intimacy that suits to further the cooperational intercourse between [the speaker] and the hearer." Eiesland \& Vindenes (2017) single out two interpretational effects, "emphasis" and "mitigation", whereas Borthen (2018) shows that the interpretational effects range from a strengthening of the speaker's emotional or epistemic attitude towards the proposition to mitigation of potentially face-threatening speech acts. Fretheim $(1995 ; 2000)$ does not mention any such interpretational effects at all.

According to Borthen (2018), the interpretational effects are pragmatic inferences that arise as a result of the specific type of contrastiveness licensed by pronominal right-dislocation (see (19)). This contrastiveness does not involve mutually excluding propositions. On the contrary, the contrasting propositions $p$ and $q$ in (19) are compatible and comparable in the sense that $p$ is interpreted in the light of $q$. The contrasting assumption $q$ contributes to the context for the utterance, and consequently, pronominal right-dislocation is expected to affect pragmatic inferences.

Example (3) in section 1 illustrates this point. The utterance with a right-dislocated pronoun in (3) is repeated in (20a) below. The utterance's propositional content $p$ is represented in (20b) and the relevant contrasting proposition $q$ in (20c).

$$
\begin{aligned}
& \text { a. Han er liksom ikke medregnet, han. } \\
& \text { 'He sort of doesn't count, HE' } \\
& \text { b. Torkild does not count (p) } \\
& \text { c. Other people count (q) }
\end{aligned}
$$

One effect of the right-dislocated pronoun in (3) is that the speaker appears as more emotionally hurt than she would have without the right-dislocated pronoun. Borthen's explanation for this is that the presence of a right-dislocated pronoun instructs the addressee to look for a 
contrastive interpretation as defined in (19), which leads to pragmatic inferences. In (3), $p$ is 'Torkild does not count', and a contextually available contrasting proposition that leads to a relevant interpretation for the utterance as a whole, is 'Other people count'. It is sad and potentially upsetting that a boy who has a handicap does not count in some people's view, but the boy's situation looks even sadder in the light of other people counting. This explains why the speaker appears as particularly emotionally hurt when she uses a right-dislocated pronoun in (3). This interpretation (that the speaker is upset) could have been reached also without the right-dislocated pronoun, but the instruction to look for a contrasting proposition gives it a "kick-start".

In (17) and (18), the right-dislocated pronouns have a slightly different type of emphasis effect, but Borthen's (ibid.) explanation is the same. The target utterances are represented in (21a) and (22a), together with the contrasting propositions in (21bc) and (22bc).
a. Ingvar Ambjørnsen ankommer 3-4 dager før, han. 'Ingvar Ambjørnsen arrives 3-4 days ahead, HE'
b. Ingvar Ambjørnsen arrives 3-4 days ahead of the performance (p)
a. Han har liksom ikke lov til å sitte slik i solen, han.
'He is not allowed to sit like this in the sun, HE'
b. He is not allowed to sit like this in the sun (p)
c. Other people are allowed to sit like this in the sun (q)

c. The other authors do not arrive 3-4 days ahead of the performance (q)

As argued in Borthen (2018), the propositions in (21b) and (22b) may not appear as particularly noteworthy in and of themselves, but this changes when interpreted in the light of (21c) and (22c). This explains why the contents of the target sentences in (17) and (18) are intuitively perceived of as being highlighted with the right-dislocated pronoun, and more generally why pronominal right-dislocation is sometimes claimed to contribute "emphasis".

As mentioned earlier, pronominal right-dislocation can also have a mitigating function (cf. Askedal 1987; Borthen 2018; Eiesland \& Vindenes 2017). For instance, in (16), Syns egentlig det er ok, jeg ('In fact, I think it is ok, I'), the right-dislocated pronoun intuitively mitigates what the speaker says. Borthen argues that also this effect is a consequence of contrastive interpretations, in (16) between 'The speaker thinks being divorced is ok' and 'The addressee does not think being divorced is ok'. However, although these intuitions seem correct, it is not entirely clear how the two seemingly incompatible pragmatic effects "mitigation" and "emphasis" arise. And more generally, it is not clear on Borthen's account how to account for the fact that the pragmatic effects are sometimes, but not always, present. The analysis that we propose in section 3 solves this puzzle. By assuming that contrastiveness is not encoded by the construction (merely made more highly accessible), it follows that the pragmatic effects are often but not always present. And since the pragmatic effects are implicatures, it is as expected that the content of the target utterance may influence the direction of the implicatures to great extent.

\subsection{Summary of previous research and desiderata}

The previous research can be summarized by six observations and remaining questions. First, unmodified and unaccented right-dislocated pronouns have been convincingly argued to always pick out the sentence topic. However, it is not clear how this can be reconciled with the fact that right-dislocated pronouns can sometimes be accented and modified by focus adverbs, in which case they do not represent the sentence topic. Moreover, it is not clear why there is a need to mark a default topic (subject or fronted object) as the topic. Secondly, a right-dislocated pronoun can sometimes affect reference assignment, but only rarely so. We have argued that this cannot be due to encoded cognitive status, but an alternative explanation for the observed effects is missing so far. Third, it has been proposed that the construction marks the present and upcoming discourse topic, which may be hypothesized to affect subsequent mentioning, but this hypothesis has failed to be empirically verified. Fourth, the construction is sometimes, but not always, used in connection with discourse breaks. Although descriptively unquestionable, it is unclear how this fact is related to other properties of the construction. Fifth, the construction often, but not always, gives rise to a specific type of contrastive interpretation, and it has been 
argued that this may lead to various pragmatic effects. However, one main challenge is to connect contrastiveness to the construction's remaining properties. And sixth, there is a need for a more explicit account of when the construction achieves the various interpretational effects, especially the emphasizing and mitigating functions, which at first glance seem incompatible. More generally, there is so far no account that successfully ties the construction's many properties together.

In the next sections, we will leave the grammatical details of the construction to further investigations and take for granted that unaccented, nonmodified right-dislocated pronouns have to have subject or fronted object correlates, and necessarily represent the sentence topic. The main contribution of our analysis is twofold. First, we will show that there is a rationale behind the fact that right-dislocated unaccented and nonmodified pronouns encode the sentence topic whereas other types of right-dislocated constituents may have a different information structure status. And secondly, we will argue that there is a connection between the construction's status as a specific type of topic construction and its effects on discourse coherence and interpretation.

\section{A holistic analysis of Norwegian pronominal right-dislocation}

\subsection{Givón's theory on marked constructions}

Givón (1983a; b) aims at predicting the likelihood for a linguistic structure to represent the sentence topic. Inspired by assumptions within gestalt psychology, he argues that continuity in discourse, both at micro and macro level, is preferable cognitively speaking, and that since predictable and highly accessible information is easier to process than nonpredictable information, languages will tend to use their most simple and least marked constructions in cases of high degree of predictability and accessibility, whereas more marked constructions will be used in cases of lower degree of predictability and accessibility.

Givón (ibid.) defines markedness such that the more phonological material, the more semantic material, and the greater morphological or syntactic complexity a linguistic form involves, the more marked it is. In line with this, hierarchies such as (23) below can be derived and used to predict whether a construction will typically be used in cases of relative continuity and predictability or the opposite (cf. Givon 1983a: 17).

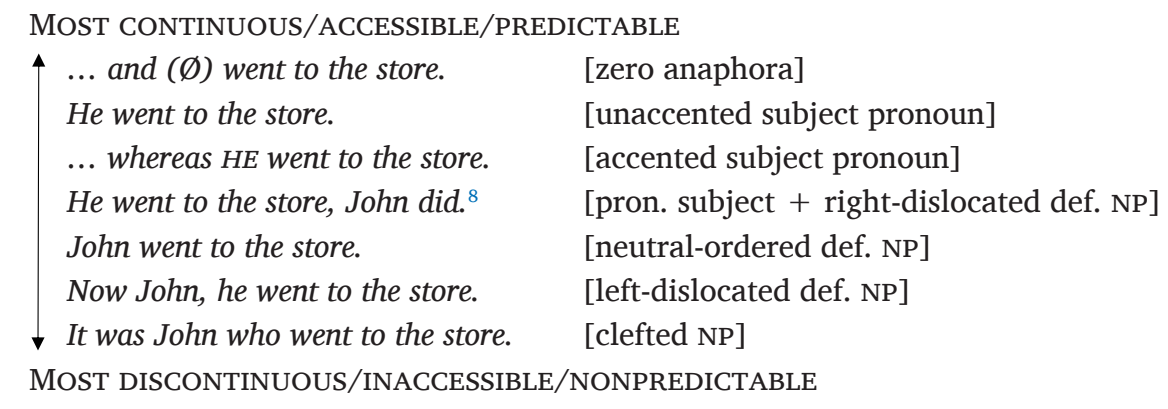

According to (23), zero elements and unaccented pronouns will be used when a referent is highly accessible and the discourse highly continuous, whereas e.g. the cleft construction is predicted to be used in cases of low degree of accessibility and predictability, i.e. when the clefted constituent represents new, unpredictable information.

Givón (1983a; b) defines topicality in terms of givenness, which means that the hierarchy in (23) represents not only the likelihood for an expression to represent predictable and continuous information, but also the likelihood for it to represent the sentence topic. This view on topicality is partly at odds with the "aboutness" definition of sentence topic presented in section 2. However, one does not have to adopt Givón's definition of topicality to make use of his notions of markedness and predictability. It is generally agreed upon that topics tend to be given and tend to be realized by certain forms. Thus, Givón's model can be used to make more

8 He went to the store, John did is the example that Givón (1983a) uses to illustrate right-dislocation, but the position in the scale in (23) would hold equally well for examples with just a right-dislocated nominal phrase, as in He went to the store, John. 
fine-grained predictions concerning these tendencies, and it can be used to explain the formfunction correlations rather than stipulating them.

The degree of predictability and continuity in Givón's model is measured relative to what would be the case for the language's more unmarked constructions. For instance, the b-versions in (24) and (25) below, with right- and left-dislocated constituents, are more marked than the a-versions, since they contain more phonological and semantic material and involve greater syntactic complexity.

a. They are really pretty.

b. $\quad$ They $_{\mathrm{i}}$ are really pretty, [those carpets $]_{i}$.

a. He never showed up.

b. $\quad$ Peter $_{\mathrm{i}}$, he $_{\mathrm{i}}$ never showed up.

Being more marked, the prediction is that the b-versions will tend to occur in cases with a lower degree of continuity and predictability than the a-versions, for instance in cases where the subject referent has not been mentioned recently.

Givón (1983a) pinpoints that predictability and continuity in the discourse applies to several levels of the discourse, including not only participant continuity (i.e. successive continuity of sentence topics), but also event continuity and thematic continuity. Thematic continuity corresponds to continuity of the discourse topic (see section 2.2), which is claimed by Givón to not correlate with linguistic forms such as those in (23) to the same extent as participant and event continuity. Event continuity corresponds primarily to temporal sequentiality and adjacency within a thematic paragraph. Most commonly, within a thematic paragraph, actions are represented in the sequential order in which they naturally occur, and typically there is a small if any temporal gap between one action and the next. According to Givón (1983a: 8), language users often choose a marker of lower accessibility (e.g. a proper name instead of a pronoun) when there is an eventive break in the discourse, e.g. in connection with time passing by, change into a new sub event, or change of perspective (see also Ariel 1990).

\subsection{Pronominal right-dislocation as a marked construction}

According to Givón's (1983a) model, pronominal right-dislocation creates a marked construction compared to the minimally distinct canonical version of the sentence. ${ }^{9}$ The scale in (26) follows from Givón's definition of markedness.

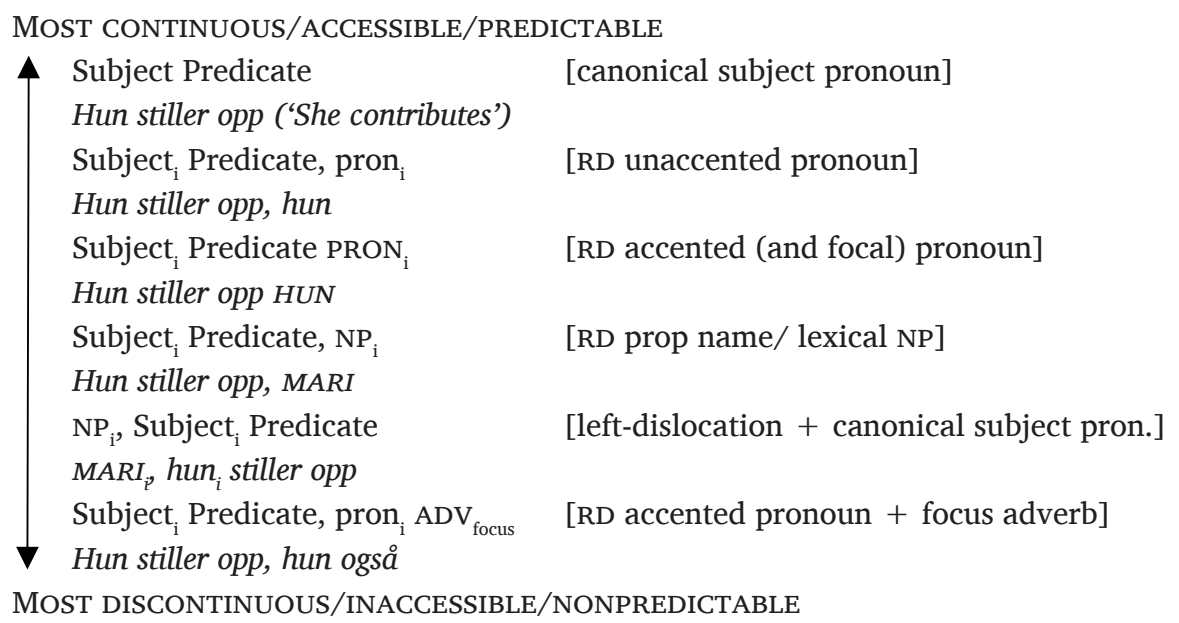

Since pronominal right-dislocation is a more marked form than the corresponding structure without the right-dislocated pronoun, it signals a lower degree of predictability and continuity of the two. At the same time, it is a construction that encodes the sentence topic, and the rightdislocated pronoun is less marked than other right-dislocated constituents, due to its "light"

9 In (26) we have contrasted minimal pairs with pronominal subject correlates, but similar scales can be derived for all types of correlates, for instance fronted objects. Deriving specific scales is, however, not a goal in itself. The crucial point is the generalization, which says that when two linguistic forms constitute a minimal pair, the one that is more marked will be associated with less degree of continuity and predictability. 
phonology and rudimentary semantics. This is compatible with cases where the target referent is a sentence topic that is just less than maximally predictable and continuous, e.g. recently mentioned but not identical to the previous sentence topic.

In all the examples that we have presented in this paper pronominal right-dislocation involves a topic shift in the sense that the current sentence topic (identified by the right-dislocated pronoun) is different from the sentence topic of the previous sentence. There are some exceptions, but the same tendency is found for the whole data set represented in Table 1. Thus, contrary to Averintseva-Klisch (2006; 2008a; b; c), who argued that pronominal right-dislocation marks the discourse topic and is a forward-looking construction, we claim that pronominal rightdislocation is a backward-looking construction: It picks out the sentence topic and signals a lower degree of predictability than otherwise expected for sentence topics, e.g., that the topic is not the same one as in the previous utterance.

In what follows, we will show that this analysis accounts for the properties summarized in section 2.6, including right-dislocated pronouns' (rare) co-occurrence with focus adverbs, the construction's possible (but rare) effect on reference assignment, its use with minor discourse breaks, its contrastive aspect, and interpretational effects.

\subsection{Differences among various types of right-dislocated constituents}

The degree of nonpredictability and discontinuity signaled by linguistic forms on a scale such as (26) will be determined by the constituent's degree of markedness, phonologically, morphosyntactically and semantically. Since an unaccented pronoun is not very complex, right-dislocated pronouns are expected to be used in cases of minor discontinuities. Rightdislocated accented pronouns and full nominal phrases, on the other hand, are semantically and phonologically more complex and thus expected to be used in cases of more serious discontinuities, possibly in reference to brand new discourse referents. These predictions are in accordance with the fact that lexical right-dislocations are often used for reference clarification due to a distant antecedent, whereas this is extremely rare for right-dislocated pronouns.

If a constituent in the right-dislocation position merely signals less degree of predictability and continuity than expected for the corresponding canonical structure, there is in principle nothing that prevents a right-dislocated constituent from being non-topical, as in the case of a rightdislocated pronoun being modified by a focus adverb (see (9)). Due to its form and content, a right-dislocated phrase consisting of a pronoun and a modifying focus adverb will be positioned towards the lower end of a scale of markedness (see (26)). On Givón's givenness account of topicality, it follows from this that the phrase is extremely unlikely to be the sentence topic. On the aboutness approach to topicality, the exact information status of such a construction has to be accounted for in other ways. However, also on this account, Givón's notion of markedness adds an explanatory aspect to the otherwise merely stipulated correlation between forms and information structure values: The correlation between a form and an information status is not random but connected to the form's degree of markedness. Although Givón's model of markedness in combination with an aboutness definition of topicality does not predict that a right-dislocated pronoun modified by a focus adverb represents non-topical information, it provides a non-stipulative rationale for why the information status is different from that of a right-dislocated unaccented pronoun.

\subsection{Connection to discourse breaks}

Since Givón (1983a) acknowledges that nonpredictability and discontinuity may appear at either the participant level or the eventive level, it is predicted that pronominal right-dislocation may be used in connection with eventive breaks, as mentioned in section 2.3. This is further illustrated with the authentic example in (27) (cf. Borthen 2018: 17).

(27) Nei, jeg la mig ikke i det hele tatt. Jeg blev sittende på sengekanten og tenke. Jeg veit ikke hvor lenge jeg hadde sittet der, jeg, men plutselig kvakk jeg til av et forferdelig hyl.

'No, I didn't go to bed at all. I just sat on my bed, thinking. I don't know how long I had been sitting there, I, but suddenly I was scared by a terrible scream.' 
In this discourse fragment, one and the same referent is the subject of three subsequent sentences, which seems to be a straight-forward case of topic continuity. However, there is an eventive break just before the sentence with the right-dislocated pronoun. Just as in (15) in section 2.3, the perspective changes from that of reporting on events that involve the given discourse referent during a certain period of time (answering the question What happened?) to that of reporting on a state that holds for the discourse referent. And intuitively, the presence of the right-dislocated pronoun compensates for the break.

It is possible to account for the connection between pronominal right-dislocation and eventive breaks with reference to information structure. Most of the sentence predicates in our data set (cf. Table 1) are stative predicates, i.e., predicates that are used to refer to properties that hold for, and are homogeneous and unchanged for, an individual over time (cf. Mittwoch 2019; Maienborn 2019). Only a few of the sentence predicates are eventive, i.e. with a lexical bias towards an interpretation where they refer to something that happens to an individual (ibid.). This tendency is not surprising given that the referent of an unaccented unmodified rightdislocated pronoun is always interpreted as the sentence topic. According to Jäger (2001), eventive predicates may supply a linguistically unexpressed topic in terms of a Davidsonian event argument while stative predicates do not. The topic of a sentence with an eventive predicate may therefore be an event variable ("concerning what happens") or an individual variable, whereas the topic of a sentence that denotes a state has to be the subject referent ("concerning this individual"). From this, it is not surprising that we find fewer eventive than stative predicates among our data.

As pointed out by Mittwoch (2019: 34), the distinction between states and events is not fully determined by the verb that is involved; a predicate that may be described as denoting an event (or have a lexical bias towards event interpretations) may achieve a stative interpretation in a particular context. Indeed, the handful of sentence predicates in our data set that have a lexical bias towards an eventive interpretation achieve a stative interpretation in the given context when a right-dislocated pronoun is present. In (17), the arrival three to four days ahead of the event is presented as a habit (and thus a state) of Ingvar Ambjørnsen rather than an event. In this sense, our data suggest that right-dislocated pronouns enforce a stative interpretation of the sentence predicate.

This can be connected to the assumption that pronominal right-dislocation is a topic construction. Given that an event interpretation that answers the question What happened? has a Davidsonian (unexpressed) event argument as the topic (cf. Jäger 2001), it is just as expected that the use of a structure that identifies a different sentence topic is incompatible with it.

We now have an explanation for Givón's observation that markers of low degree of predictability are not only used with referential discontinuity, but also eventive discontinuity. In examples such as (15B1) and (27), the same referent is referred to in subject position in two adjacent sentences, the second time with an accompanying right-dislocated pronoun. Our explanation for why pronominal right-dislocation is often used in such cases, is that the first sentence despite the subject pronoun - has an eventive variable as its sentence topic (answering the question What happened?), whereas the second sentence has the referent of the right-dislocated pronoun as its sentence topic. This means that the sentence topic changes from one sentence to the other, there is discontinuity, and the use of a marked topic construction becomes highly appropriate.

\subsection{Marked constructions, nonpredictability and contrast}

Contrastiveness is not a central aspect of Givón's (1983a) work, but both Givón (1983a) and Ariel (1990) do mention competition as one factor that affects referent accessibility. Moreover, it can be observed that marked constructions often give rise to contrastive interpretations. Consider the minimal pair in (28). The subject constituent of (28b) is accented and thus more marked than the subject in (28a) in Givón's (1983a) sense.

a. She had no problem talking to her.

B. She had no problem talking to her.

Intuitively, a contrastive interpretation comes easier to mind for (28b) than for (28a). A natural context for (28b) is a situation with more than one activated female discourse referent, where 
the predication that holds for the subject referent does not hold for some competing referent candidate. The tendency for accented pronouns to license contrastive interpretations has also been observed in the literature (see e.g. Rooth 1992: 7; McClay \& Wagner 2015).

A similar pattern holds for fronted objects. Being structurally more complex, (29b) is more marked than (29a), according to Givón (1983a).

$$
\text { a. I spoke to Ann on Skype. }
$$$$
\text { b. Ann I spoke to on Skype. }
$$

As described in e.g. Ward \& Birner (2004), topicalized phrases as in (29b) may have one of two functions in English, one of which is a contrastive topic interpretation (see also Roberts 1996; Krifka 2007).

Also left-dislocation is particularly natural in situations where the given discourse referent is being contrasted to other accessible discourse referents. (30) illustrates this.
a. Peter never showed up.
b. Peter, he never showed up.

Observations in the literature point in the same direction (see e.g. Chafe 1976), thus associating left-dislocation with contrastiveness.

Based on data such as (28)-(30) and the related literature, we conclude that other things being equal, marked constructions make contrastive interpretations more highly accessible than the corresponding unmarked ones.

There are at least two ways in which this follows from Givón's (1983a) model. First, a contrastive interpretation often involves a context with competition among potential discourse referents, which means that the intended referent of the given expression is not maximally accessible. Some types of contrastiveness are also linked to marked constructions in a more general way. For instance, an assumption that contrasts with what is known, in the sense of having opposite polarity to it, is surprising and thus nonpredictable. And an assumption about a certain individual which contrasts with what holds for other individuals (see e.g. (16) and (17)) may also come as a surprise. Thus, contrastive interpretations constitute the kind of meaning that one might expect to be communicated through marked constructions. This means that there is no need to assume that contrastiveness is encoded in the semantics of each type of marked construction; rather, it is a meaning aspect that is made more highly accessible by any marked form compared to its minimally distinct unmarked version.

In terms of the type of contrastive interpretation it gives rise to, pronominal right-dislocation differs from the marked constructions discussed above. Compare the examples in (31).

\footnotetext{
a. Øystein , han $_{i}$ kan bare spille roller som seg selv. 'Øystein, he can only play roles as himself'

b. Øystein ${ }_{i}$ kan bare spille roller som seg selv, han ${ }_{i}$. 'Øystein can only play roles as himself, HE'
}

In (31a), the markedness of the structure is evident already after the second constituent has been processed. Given that the addressee starts searching for a contrastive interpretation at this point, a likely option is to look for alternative referents against which Øystein can be contrasted. In (31b), on the other hand, the markedness of the structure is not evident until the whole utterance has been processed. In such cases, the addressee can use the content of the sentence (as well as pragmatically enriched versions of it) as a basis for identifying potentially contrasting entities. This means that the contrasting entity may be a proposition and it means that the contrasting proposition need not be contextually accessible prior to the utterance, as in (16) and (17); it may be derived through pragmatic inferencing based on the utterance content and whatever contextual clues are otherwise available, as in (18).

Since the two types of dislocation in (31a) and (31b) represent different degrees of markedness, and give access to different types of contrast, this explains why they are sometimes combined and mark the sentence topic twice, as in (8). The constructions are compatible as long as they pick out the same sentence topic. To add a left-dislocated phrase to a sentence with a 
right-dislocated pronoun may be relevant due to its descriptive content, that enables reference identification, and to add a right-dislocated pronoun to a sentence with a left-dislocated phrase may be desirable due to the specific type of propositional contrast that the construction gives rise to.

We define the type of contrast involved in pronominal right-dislocation as in (32), which is a revised version of Borthen's (2018) definition discussed in section 2.2.

The type of contrast involved in pronominal right-dislocation:

There is contrast between two propositions $p$ ([TOPIC COMMENT $\left._{1}\right]_{\text {Tnd }} q$ [TOPIC $_{2}$

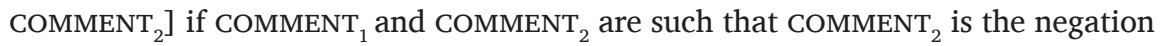
of COMMENT . $_{1}$

To illustrate this, in (16), based on the topic-comment structure of the sentence with the rightdislocated pronoun, the proposition " $[\mathrm{I}]_{\text {TOPIC1 }}$ [think it is ok (to be separated) $]_{\text {COMMENT1 }}$ " can be compared to "[Some people $]_{\text {TOPIC2 }}$ [do not think it is ok to be separated $]_{\text {COMMENT2 }}$ ", where

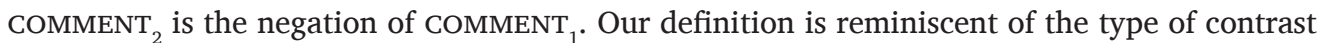
called semantic opposition in Lakoff (1971) and defined in Spooren (1989: 31) as "a relation between two conjuncts each having different subjects, to which properties are attributed that are mutually exclusive in the given context".

Summing up so far, we assume with Givón (1983a; b) that marked constructions signal nonpredictability and discontinuity compared to minimally distinct unmarked forms, and since pronominal right-dislocation is a marked construction, it gives rise to such interpretations. However, differently from Givón (1983a), we have argued that marked constructions in general heighten the accessibility of contrastive interpretations. This means that for pronominal rightdislocation, signalling nonpredictability may instantiate itself in one of two ways, or both: Either the construction indicates that the sentence topic that is identified is less predictable than expected for sentence topics (as in the case of topic shifts), or it indicates a particular type of contrastive interpretation based on the topic-comment structure of the sentence, i.e. lower predictability of the entire sentence content.

\subsection{Effects on reference assignment}

We are now in the position to explain why the right-dislocated pronoun in (12) affects reference assignment. Recall the data: Whereas the subject pronoun in (11) Den har et siksakband over ryggen 'It has a zigzag band down its back' is interpreted as referring to the particular viper that the addressee just mentioned, the same pronoun in the same position and context is more naturally interpreted as the 'species viper' when a right-dislocated pronoun is added, as in (12). Fretheim (1995) explains these data by an analysis which focuses on reference assignment only and implicates considerable enumeration of the meaning of determiners and pronouns in the lexicon. Our explanation is more general. The target sentence in (12) is a marked topic construction, which means that the addressee can expect some kind of discontinuity or nonpredictability compared to what would have been the case without the right-dislocated pronoun, i.e. a topic shift and/or a contrastive interpretation as defined in (32). If the pronoun den is interpreted as the particular viper just mentioned, this expectation is not borne out, whereas it is borne out if the pronoun is interpreted as the species viper. In the latter case, the sentence topic shifts from the first to the second utterance. Moreover, (12) achieves a contrastive interpretation, a fact that Fretheim (1995) fails to observe. Also the contrastive aspect of the construction contributes to the given reference assignment, since interpreting the proposition 'the species viper has a zigzag band down its back' in the light of the contrasting assumption 'the snake over there does not have a zigzag band down its back' provides an explanation for why the speaker does not think the given snake is a viper. In sum, this explains the difference between (11) and (12) without the need of lexical enumeration.

\subsection{Explaining pragmatic effects}

Borthen (2018) argued that it is the contrastive aspect of pronominal right-dislocation that gives rise to interpretational effects such as a strengthening of the speaker's epistemic or emotional attitude towards the proposition or a weakening of a potentially face-threatening speech act. What is not entirely clear from Borthen's account, though, is how one single construction 
can result in diametrically opposite effects ("emphasis" or "mitigation"). In this section, we illustrate how pragmatic interpretations may be derived in context, with a special focus on this alleged interpretational paradox.

According to relevance theory, the overall comprehension process involves three basic subtasks: a) constructing an appropriate hypothesis about explicit content (the utterance's explicatures), b) constructing an appropriate hypothesis about the intended contextual assumptions (implicated premises), and c) constructing an appropriate hypothesis about the intended contextual implications (implicated conclusions) (Wilson \& Sperber 2004: 615; Sperber \& Wilson 1986/1995; Carston 2002). An explicature is an ostensively communicated truth-evaluable proposition which is a development ("fleshing out") of the encoded concepts of the utterance. Explicatures may be used as vehicles together with contextual assumptions for the generation of implicatures, i.e. communicated assumptions whose derivation is based solely on pragmatic inference. Importantly, context is not a static entity that exists prior to an utterance on this view; rather, context is a mental object, i.e. the set of manifest assumptions that are needed in order to interpret an utterance.

On the relevance-theoretic account of the pragmatic effects of pronominal right-dislocation that we propose, the so-called "emphasis" and "mitigation" effects are implicatures. More precisely, the contrasting proposition $q$ in (32) can function as a contextual assumption in light of which the utterance's most relevant (basic or higher-level) explicature $p$ ought to be interpreted which may in turn lead to implicated conclusions that contribute an extra "layer" of meaning.

The relevance-theoretic framework accounts for the fact that communication can be either strong, where the speaker's informative intentions are clear because there is strong evidence for them, or weak, where the speaker produces an utterance that opens for a number of possible implications, expecting that at least some of them will be fruitful enough for the addressee to offset the needed processing costs (Sperber \& Wilson 1995: 197). Correspondingly, implicatures can be either strong or weak, and some of the implicatures that pronominal right-dislocation give rise to, may be weak in this sense.

A sentence with pronominal right-dislocation underdetermines several meaning aspects, including i) whether the speaker intends a contrastive interpretation or not (the marked construction may also be used for the purpose of signaling topic shift only), ii) which propositions ought to be contrasted, and iii) which implicatures to derive from the contrasting proposition in combination with the utterance content and other contextual assumptions. Thus, one might wonder how the addressee is able to land on an interpretation at all. The relevance-theoretic explanation for this rests ultimately on The communicative principle of relevance (Sperber \& Wilson 1987/1995: 158), which is a heuristics for utterance interpretation. This principle says that when we process an utterance, we expect the processing cost that we invest to be worthwhile, i.e. optimally relevant. Relevance is measured in terms of a balance between processing effort and positive cognitive effects, where a positive cognitive effect is a worthwhile change in a person's representation of the world (Wilson \& Sperber 2004: 608). In accordance with this, a right-dislocated pronoun raises the expectation that the addressee will either benefit a decrease in processing effort (as may be the case when signaling topic shift) or obtain extra cognitive effects that would not otherwise be (as) available.

Concerning the interpretational effects, the relevance-theoretic prediction is that the addressee will look for interpretations that yield the most cognitive effects for the least processing effort. Moreover, he or she will take into consideration the most accessible (least processing demanding) contextual assumptions first and stop the interpretation process as soon as enough cognitive effects are derived. Less accessible contextual assumptions may be accessed and more costly cognitive effects derived if that is needed to achieve the expected level of relevance.

We can now explain the interpretational effects that have been observed for pronominal right-dislocation, e.g. the fact that the speaker seems more emotionally hurt in (3) when a right-dislocated pronoun is present. The right-dislocation makes the utterance marked, which heightens the accessability of a contrastive interpretation. In (3), the explicature 'Torkild does not count', does contribute relevant information in and of itself, but much more so if interpreted in light of the contrasting proposition 'Other people count' and various assumptions about Torkild, such as Torkild being a special and vulnerable boy. From these and other contextual assumptions, the conclusion 'The speaker is upset that Torkild is treated worse than other 
people' may be derived, which provides extra cognitive effects to compensate for the extra effort imposed by the processing of the right-dislocated pronoun. The addressee might have landed on the same interpretation also without the right-dislocated pronoun, but with the pronoun, the addressee gets a hint to look for some extra cognitive effects, and the specific interpretation gets a kick-start due to the heightened accessibility of a contrastive interpretation.

\subsubsection{Contrast leads to strengthening}

(33) below is an example which illustrates the potential strengthening ("emphasis") effect of pronominal right-dislocation. In the situation in which (33) occurs, the speaker is having a row with a young man. The speaker shouts to a woman named Marie before he turns to the young man and continues his speech.

- Marie, brølte han plutselig. - Marie, kom med selters. Så fortsatte han snerrende: Du tror du er noe, du. Men du er bare en drittgutt [...].

'- Marie, he suddenly shouted. - Marie, bring the selters. Then he continued, sneering: - You think you are someone, YOU. But you are just a lousy coward [...].'

The presence of the right-dislocated pronoun has two main effects here. First, it makes the utterance appear as more coherent than it would have without the right-dislocated pronoun, and secondly, it makes the speaker appear as particularly scornful, disrespectful and provoking. Both these effects can be explained on the present account. Being a marked topic construction, the pronoun signals lower degree of continuity and predictability than expected for a pronominal subject. In other words, the pronoun compensates for the shift of sentence topic in the transition to the target sentence in (33). As for the extra emotional strength of the utterance, this can be attributed to the heightened accessibility of a contrastive interpretation. The explicature of the target utterance in (33) is 'You [ = the addressee] think you are someone good'. In the given context, with a high level of conflict, a particularly relevant interpretation is achieved if the utterance is interpreted in light of the contrasting proposition 'Other people do not think you are someone good'. This contrast between other people's negative view on the addressee and the addressee's positive view on himself is likely to give rise to various (weak or strong) implicatures that are all negative evaluations of the addressee and his high self esteem - which explains why the utterance appears as particularly scornful, disrespectful and provoking with the right-dislocated pronoun.

This is a case where pronominal right-dislocation has the effect of strengthening the speaker's emotional attitude towards the utterance's basic proposition, i.e. a case that fits the general (and too vague) interpretational label "emphasis". Some other examples that exemplify the strengthening function of right-dislocated pronouns are (8), (10), (12), (14a), (17) and (18). In such examples, the right-dislocated pronoun has the secondary effect of presenting the propositional content as particularly noteworthy or remarkable, which can be traced back to contrastive interpretations. One thing these examples have in common is that the speaker appears as epistemically certain independently of the right-dislocated pronoun. We have observed the following tendency: If a speaker uses a right-dislocated pronoun in an utterance with a high degree of epistemic certainty, the contrast between $p$ and $q$ in (32) tends to lead to a strengthening of $p$ i.e. an interpretation that might broadly be described as "emphasis".

\subsubsection{Contrast leads to mitigation}

Next, consider (34) from Borthen (2018: 435), in which the interpretational effects of the rightdislocated pronoun are of a completely different sort. The conversation takes place between two friends who are hiking in the woods. Kalle is in the tent, and his friend talks to him.

- Myggen biter i alle fall ... Håper fisken gjør det samme. Blir’u med en tur, Kalle.

- Trur jeg mediterer litt, jeg.

'- The mosquitos are biting, at least ... I hope the fish will bite as well. Will you join me, Kalle?

- I think I'll rather meditate for a while, I.'

In this case, the presence of the right-dislocated pronoun makes the utterance milder and less confronting than what would have been the case without it. However, also this effect is 
compatible with the proposed analysis of the construction. Being a marked topic construction, the pronoun indicates a lower degree of continuity and predictability than otherwise expected, and thus makes a contrastive interpretation more highly accessible. In this situation, there is a highly accessible contrastive relation evoked by the situation, namely between the addressee's desire for Kalle to go fishing and Kalle's desire to meditate and thus not go fishing. The reason why the contrastive aspect makes the utterance appear as milder in this case, is partly due to the utterance content and partly to the more general context. From the prior discourse it seems likely that the interlocutors are friends and want to stay friends. Thus, contextual assumptions and cognitive effects that support such a hypothesis will be particularly easily available. Furthermore, although the speaker expresses that he wants to meditate, he does so in a rather weak way. The Norwegian verb tro 'think, believe' suggests that the speaker is not fully confident about his choice. When the speaker chooses to include a right-dislocated pronoun, which gives more easy access to a contrasting proposition which acknowledges the addressee's opposing view, the effect is more of an invitation to objection than a sign of confrontation. After all, if you state something with uncertainty ('I think I should meditate, but I am not sure'), and suggest that other people may not agree in what you state ('You think I should not meditate'), you are likely to seem even more uncertain. Thus, it is not surprising that the speaker's utterance in (34) appears as epistemically weaker with the right-dislocated pronoun than without it.

What is common to (34) and similar examples, such as (16), is that there are some aspects of the utterance or the context that makes it likely that the speaker does not want to make an epistemically strong statement. Either the utterance represents the speaker's personal view, which may be contested, or the utterance contains some expressions of uncertainly. In (34), the subject and the main verb are jeg tror ('I think'), and in (16) it is clear that the speaker presents her personal point of view after being presented to the addressee's point of view. The pattern can be formulated as follows: If a speaker uses a right-dislocated pronoun in an utterance with a low degree of epistemic certainty, the contrast between $p$ and $q$ in (32) tends to lead to a weakening of $p$, i.e. an interpretation that might broadly be described as "mitigation".

\section{Conclusions and further research}

In this paper, we addressed the phenomenon of pronominal right-dislocation in Norwegian and presented an account that ties together the construction's central properties. These properties include the construction's status as a topic construction as well as various discourse properties, such as its (rare) ability to affect reference assignment, its tendency to be used in cases with minor discourse breaks, its association with contrastiveness, and the fact that it may cause interpretational effects such as "emphasis" and "mitigation". Although these properties have been extensively discussed in the literature, no satisfactory account that brings them together has existed up to date.

Three previous accounts have been critically examined. Fretheim's (1995) proposal that pronominal correlates that co-occur with a right-dislocated pronoun encode a different cognitive status than canonical pronouns, was argued to lead to an unnecessary high number of discontinuous items in the lexicon and argued to be impossible to maintain for descriptive reasons. Averintseva-Klisch's (2006; 2008a; b; c) analysis of right-dislocated pronouns as markers of the present and upcoming discourse topic was questioned based on an empirical investigation that shows that the use of a right-dislocated pronoun does not increase its likelihood of being referred to subsequently. And finally, Borthen's (2018) account was criticized for a non-satisfactory definition of contrast, for overlooking the fact that the contrastive aspect of the construction is not always present, and for not being entirely clear on how the construction can lead to effects as distinct as "emphasis" and "mitigation".

According to Givón (1983a), languages use their most simple and unmarked forms for continuity and predictability whereas more marked forms are used in cases where continuity and predictability is not maximally maintained. In line with this, we have argued that pronominal right-dislocation in Norwegian is not only a topic construction, but a marked topic construction whose function is to indicate a lower degree of predictability of the sentence's
Borthen and Karagjosova Glossa: a journal of general linguistics DOI: 10.5334 /gjgl.1025 
topic or topic-comment structure than what would have been expected for the minimally distinct structure without pronominal right-dislocation. In effect, the construction is used to indicate a shift of sentence topic from the previous utterance to the current one, and/or that what is stated about the topic referent contrasts with what is expected or given. This explains why the construction is often used in cases of eventive breaks and why it may in some rare cases influence reference assignment. The construction is predicted to be unacceptable if the context is such that the right-dislocated pronoun has to represent non-topical information, or the right-dislocated pronoun represents a continuous topic while there is no contrastive interpretation.

By assuming that marked constructions in general heighten the accessibility of contrastive interpretations, we have also been enabled to explain the construction's pragmatic effects. The explanation goes as follows: Just like colours look different depending on the colours that surround them, the way we view facts is affected by their "surrounding" contextual assumptions. What might appear as a trivial opinion in some circumstances may seem highly noticeable and "emphasized" when it is viewed in opposition to other people's opinion. Or conversely, if the speaker expresses that he or she is uncertain about some assumption, then directing the addressee's attention towards the existence of opposite views may make the utterance's epistemic status weaker and more open to the addressee's objections, and thus "mitigated". This way, the contrasting proposition that a right-dislocated pronoun may give rise to will affect what implicatures to derive from the utterance. Such inferences include (but are not in principle restricted to) a strengthening of the speaker's epistemic or emotional attitude towards the proposition (i.e. "emphasis") or a weakening of the speaker's epistemic stance towards the proposition (i.e. "mitigation"). On this account, "emphasis" and "mitigation" are only approximate umbrella terms for an in principle unlimited set of possible implicatures; unlimited in the sense that the set cannot be exhaustively listed, but restricted in the sense that it is the result of interpreting the utterance content in the light of a specific type of contrasting contextual assumptions. This explains the otherwise puzzling fact that one and the same construction can result in two diametrically opposite effects.

Many questions, including the grammatical properties of the construction, are left for further research. We have not explicated the details of how the information status of a rightdislocated pronoun changes if modified by a focus adverb; only that this is reasonable since the construction then becomes more marked. We have also refrained from presenting any numbers on how frequent the two main functions (topic discontinuity and contrastiveness) are, and to what extent they co-occur; this must be followed up in later studies. Moreover, although we have presented a model for how pronominal right-dislocation is connected to other types of right-dislocation (the prediction being that the more marked the form, the less degree of predictability and continuity), there is a need for corpus studies that systematically compare the discourse properties and pragmatic effects of various types of right-dislocation.

Since we have focused only on Norwegian data, a second natural follow-up study is to investigate to what extent the observed interpretations for Norwegian pronominal right-dislocation recur cross-linguistically. Judging from the descriptions in e.g. Ashby (1988) and Snell (2018), some of the effects of pronominal right-dislocation in French and vernacular oral English are similar to those observed in Norwegian, but more detailed language-specific descriptions and cross-linguistic studies are needed. It is expected that recurring pragmatic inferences may be conventionalized over time. To what extent this has happened with pragmatic inferences associated with pronominal right-dislocation in Norwegian and other languages, can be evaluated more appropriately if we compare the phenomenon across languages.

\section{Abbreviations}

$$
\begin{aligned}
& \mathrm{DEF}=\text { definite } \\
& \mathrm{M}=\text { masculine } \\
& \mathrm{N}=\text { neuter } \\
& \mathrm{PL}=\text { plural } \\
& \mathrm{SG}=\text { singular }
\end{aligned}
$$




\section{Additional files}

The additional files for this article can be found as follows:

- Pronominal right-dislocation in Norwegian_full data set. 289 Norwegian text excerpts with sentences with right-dislocated pronouns. DOI: https://doi.org/10.5334/gjgl.1025.s1

- Annotated data Pronominal right-dislocation in Norwegian_reference maintenance. 207 minimal pairs of text fragments with and without pronominal right-dislocation, annotated for subsequent mention of target referent. DOI: https://doi.org/10.5334/gjgl.1025.s2

\section{Acknowledgements}

We would like to thank three anonymous reviewers for their valuable suggestions.

\section{Competing interests}

The authors have no competing interests to declare.

\section{Author affiliations}

Kaja Borthen (iD) orcid.org/0000-0002-1183-6415

NTNU Trondheim, NO

Elena Karagjosova (D) orcid.org/0000-0003-4181-9576

FU Berlin, DE

\section{References}

Aijmer, Karin. 1989. Themes and tails: The discourse functions of dislocated elements. Nordic Journal of Linguistics 12. 137-53. DOI: https://doi.org/10.1017/S033258650000202X

Ariel, Mira. 1990. Accessing NP antecedents. London: Routledge.

Askedal, John Ole. 1987. On the morphosyntactic properties and pragmatic functions of correlative right dislocation (right copying) in modern colloquial Norwegian. In Pirkko Lilius \& Mirja Saari (eds.), The Nordic languages and modern linguistics 6. 93-110. Helsinki: Helsinki University Press.

Averintseva-Klisch, Maria. 2006. 'Separate performative' account of German right dislocation. Proceedings of the Sinn und Bedeutung 10(1). 15-28. DOI: https://doi.org/10.21248/zaspil.44.2006.297

Averintseva-Klisch, Maria. 2008a. Dislocating NPs to the right: Anything goes? Semantic and pragmatic constraints. In Atle Grønn (ed.), Proceedings of SuB 12, 32-46. University of Oslo.

Averintseva-Klisch, Maria. 2008b. German right-dislocation and afterthought in discourse. In Anton Benz \& Peter Kühnlein (eds.), Constraints in discourse, 213-235. Amsterdam: John Benjamins Publishing Company. DOI: https://doi.org/10.1075/pbns.172.11ave

Averintseva-Klisch, Maria. 2008c. To the right of the clause. Right-dislocation vs. afterthought. In Cathrine Fabricius-Hansen \& Wiebke Ramm (eds.), 'Subordination' versus 'coordination' in sentence and text: A cross-linguistic perspective, 217-239. Amsterdam: John Benjamins Publishing Company. DOI: https://doi.org/10.1075/slcs.98.12ave

Biber, Douglas, Stig Johansson, Geoffrey Leech, Susan Conrad \& Edward Finegan. 1999. Longman grammar of spoken and written English. Harlow: Longman.

Blakemore, Diane. 1987. Semantic constraints on relevance. Oxford: Blackwell.

Borthen, Kaja. 2018. Pronominal høyredislokering, det er et interessant fenomen, det. [Pronominal rightdislocation, that is an interesting phenomenon, that]. Norsk Lingvistisk Tidsskrift 36. 403-450.

Carston, Robyn. 2002. Thoughts and utterances. The pragmatics of explicit communication. Oxford: Blackwell Publishing. DOI: https://doi.org/10.1002/9780470754603

Carter, Ronald \& Michael McCarthy. 1995. Grammar and the spoken language. Applied Linguistics 16. 141-158. DOI: https://doi.org/10.1093/applin/16.2.141

Carter, Ronald \& Michael McCarthy. 1997. Exploring spoken English. Cambridge: Cambridge University Press.

Carter, Ronald, Rebecca Hughes \& Michael McCarthy. 2000. Exploring grammar in context. Cambridge: Cambridge University Press.

Chafe, Wallace. 1976. Givenness, contrastiveness, definiteness, subjects, topics, and point of view. In Charles Li (ed.). Subject and topic, 25-55. NY: Academic Press.

Dik, Simon C. 1978. Functional grammar. Amsterdam: North-Holland.

Eiesland, Eli Anne \& Urd Vindenes. 2017. "Du e mislykka, du": en korpusundersøkelse av subjektsdublering i norsk. [«You are a failure, you»: a corpus investigation of subject duplication in Norwegian]. Paper presented at Møter om norsk språk 17, University of Bergen. 
Faarlund, Jan Terje, Svein Lie \& Kjell Ivar Vannebo. 1997. Norsk referansegrammatikk. [Norwegian reference grammar]. Oslo: Universitetsforlaget.

Fretheim, Thorstein. 1995. Why Norwegian right-dislocated phrases are not afterthoughts. Nordic Journal of Linguistics 18(1). 41-54. DOI: https://doi.org/10.1017/S0332586500003097

Fretheim, Thorstein. 1999. "Det er bare det at...”. [«It’s just that...»]. Norsk Lingvistisk Tidsskrift 17(1). $155-170$

Fretheim, Thorstein. 2000. The interaction of right-dislocated pronominals and intonational phrasing in Norwegian. Proceedings of the VIIIth Conference Nordic prosody. Trondheim.

Givón, Talmy. 1983a. Introduction. In Talmy Givón (ed.), Topic continuity in discourse. A quantitative crosslanguage study, 5-35. Amsterdam: John Benjamins. DOI: https://doi.org/10.1075/tsl.3

Givón, Talmy (ed.). 1983b. Topic continuity in discourse. A quantitative cross-language study. Amsterdam: John Benjamins. DOI: https://doi.org/10.1075/tsl.3

Gundel, Jeanette, Nancy Hedberg \& Ron Zacharski. 1993. Cognitive status and the form of referring expressions in discourse. Language 69(2). 274-307. DOI: https://doi.org/10.2307/416535

Gundel, Jeanette \& Thorstein Fretheim. 2004. Topic and focus. In Laurence Horn \& Gregory Ward (eds.), The handbook of pragmatics, 175-196. Oxford: Blackwell. DOI: https://doi. org/10.1002/9780470756959.ch8

Jäger, Gerhard. 2001. Topic-comment structure and the contrast between stage level and individual level predicates. Journal of Semantics 18(2). 83-126. DOI: https://doi.org/10.1093/jos/18.2.83

Jörgensen, Nils. 1976. Meningsbyggnaden i talad svenska. Studentlitteratur: Lund.

Karagjosova, Elena. 2012. On the discourse function of particles in post-initial position. Lingua 122. 1819-1842. DOI: https://doi.org/10.1016/j.lingua.2012.08.002

König, Ekkehard. 1991. The meaning of focus particles. A comparative perspective. London: Routledge.

Krifka, Manfred. 2007. Basic notions of information structure. In Caroline Féry, Gisbert Fanselow \& Manfred Krifka (eds.), The notions of information structure. Potsdam: Universitätsverlag.

Lakoff, Robin. 1971. If's, and's, and but's about conjunction. In Charles Fillmore \& D. Terence Langendoen (eds.), Studies in Linguistic Semantics, 115-150. New York: Holt, Reinhart and Winston.

Lambrecht, Knud. 1994. Information structure and sentence form. Topic, focus and the mental representation of discourse referents. Cambridge: Cambridge University Press. DOI: https://doi.org/10.1017/ CB09780511620607

Maienborn, Claudia. 2019. Events and states. In Robert Truswell (ed.), Handbook of event structure, 50-89. Oxford: Oxford University Press. DOI: https://doi.org/10.1093/oxfordhb/9780199685318.013.6

McClay, Elise \& Michael Wagner. 2015. Accented pronouns and contrast. In Proceedings of the 50th Meeting of the Chicago Linguistics Society.

Mittwoch, Anita. 2019. Aspectual Classes. In Robert Truswell (ed.), The Oxford handbook on event structure. Oxford: Oxford University Press. DOI: https://doi.org/10.1093/ oxfordhb/9780199685318.013.4

Mycock, Louise. 2019. Right-dislocated pronouns in British English: The form and functions of ProTag constructions. English Language and Linguistics 23(2). 253-275. DOI: https://doi.org/10.1017/ S1360674317000399

Nyholm, Leif. 1986. Svansdubbleringen den västnyländska. [Tail doubling in the Swedish dialects of Nyland, Finland]. In Mirja Saari, Anne-Marie Londen \& Kim Nilsson (eds.), Xenia Huldeniana. En vänskrift tillägnad Lars Huldén på hans 60-årsdag, 205-217. Helsingfors: Institutionen för nordiska språk och nordisk litteratur vid Helsingfors Universitet.

Reinhart, Tanya. 1981. Pragmatics and linguistics. An analysis of sentence topics. Philosophica 27. 53-94.

Roberts, Craige. 1996. Information structure in discourse: Towards an integrated formal theory of pragmatics". In J. H. Yoon \& Andreas Kathol (eds.), OSU Working Papers in Linguistics 49: Papers in Semantics, 91-136. Columbus: Ohio State University.

Rooth, Mats. 1992. A theory of focus interpretation. Natural Language Semantics 1. 75-116. DOI: https:// doi.org/10.1007/BF02342617

Shorrocks, Graham. 1999. A grammar of the dialect of the Bolton area, part II: Morphology and syntax. Frankfurt am Main: Peter Lang.

Snell, Julia. 2018. Solidarity, stance and class identities. Language in Society 47. 665-691. DOI: https://doi. org/10.1017/S0047404518000970

Søfteland, Åshild. 2014. Utbrytingskonstruksjonen i norsk spontantale. [The cleft construction in Norwegian spontaneous speech]. Ph.D. thesis, Olso University.

Sperber, Dan \& Deirdre Wilson. 1986/1995. Relevance. Communication and cognition. Oxford: Blackwell.

Spooren, Wilbert. 1989. Some aspects of the form and interpretation of global contrastive coherence relations. Ph.D. thesis, Nijmegen.

Teleman, Ulf \& Anne-Marie Wieselgren. 1970. ABC i stilistik. [ABC in stylistics]. Lund: Gleerups.

Timmis, Ivor. 2010. 'Tails' of linguistic survival. Applied Linguistics 31(3). 325-345. DOI: https://doi. org/10.1093/applin/amp028
Borthen and Karagjosova Glossa: a journal of general linguistics DOI: 10.5334 /gjgl.1025 
Vangsnes, Øystein Alexander. 2008. On peripheral doubling in Scandinavian. In Sjef Barbiers et al. (eds.), Microvariation in syntactic doubling, 419-441. Bingley: Emerald. DOI: https://doi. org/10.1163/9781848550216_017

Ward, Gregory \& Betty Birner. 2004. Information structure and non-canonical syntax. In Laurence Horn \& Gregory Ward (eds.), Handbook of pragmatics, 153-174. Oxford: Blackwell.

Wilson, Deirdre \& Dan Sperber. 1993. Linguistic form and relevance. Lingua 90. 1-25. DOI: https://doi. org/10.1016/0024-3841(93)90058-5

Wilson, Deirdre \& Dan Sperber. 2004. Relevance theory. In Laurence Horn \& Gregory Ward (eds.), Handbook of pragmatics, 607-632. Oxford: Blackwell.

Wright, Joseph. 1905. The English dialect grammar. Oxford: Henry Frowde.

Ziv, Yael. 1994. Left and right dislocations: Discourse functions and anaphora. Journal of Pragmatics (22). 629-645. DOI: https://doi.org/10.1016/0378-2166(94)90033-7

\section{Corpus}

The Oslo Corpus. University of Oslo. 'Bokmålsdelen'. http://www.hf.uio.no/iln/tjenester/kunnskap/sprak/ korpus/skriftsprakskorpus/oslo/.
Borthen and Karagjosova

Glossa: a journal of

general linguistics

DOI: 10.5334 /gjgl.1025
TO CITE THIS ARTICLE: Borthen, Kaja and Elena Karagjosova. 2021. Pronominal right-dislocation in Norwegian. Glossa: a journal of general linguistics 6(1): 85. 1-25. DOI: https://doi.org/10.5334/ gjgl.1025

Submitted: 18 June 2019 Accepted: 26 May 2021 Published: 01 July 2021

\section{COPYRIGHT:}

(c) 2021 The Author(s). This is an open-access article distributed under the terms of the Creative Commons Attribution 4.0 International License (CC-BY 4.0), which permits unrestricted use, distribution, and reproduction in any medium, provided the original author and source are credited. See http:// creativecommons.org/ licenses/by/4.0/.

Glossa: a journal of general linguistics is a peer-reviewed open access journal published by Ubiquity Press. 